\title{
НАУКОВО-ПРАКТИЧНІ АСПЕКТИ СТВОРЕННЯ АДАПТОВАНИХ ДО КЛІМАТИЧНИХ ЗМІН СОРТІВ І ГІБРИДІВ СІЛЬСЬКОГОСПОДАРСЬКИХ КУЛЬТУР ТА ТЕХНОЛОГІЙ ЇХ ВИРОЩУВАННЯ В УМОВАХ ЗРОШЕННЯ ПІВДНЯ УКРАЇНИ
}

\section{Вожегова P. А.}

\section{ВСТУП}

На підставі моделювання процесів змін клімату, проведеного вченимикліматологами Кембриджської групи з різних країн світу під егідою ФАО $\mathrm{OOH}$, прогнозується і подальше підвищення температури повітря в діапазоні від 2 до $6^{\circ} \mathrm{C}$ у період до 2100 року ${ }^{1}$. Таке зростання температури та концентрації $\mathrm{CO}_{2}$ в повітрі матимуть безпосередній вплив на біосферу Землі, в тому числі й на продуктивність агропромислового комплексу, врожайність і якість продукції сільськогосподарських культур. До негативних змін клімату на найближчу перспективу можна віднести підвищення температури повітря, посилення дії посух, скорочення сніжного покриву, порушення рівномірності надходження атмосферних опадів, що в комплексі призводить до активізації ерозійних процесів та деградації грунтів.

Підвищення посушливості клімату викликало необхідність зміни підходів до формування систем ведення землеробства, особливо в умовах Південного Степу України. За останні 45 років сума ефективних і позитивних температур за вегетаційний період у цьому регіоні зросла майже на $700^{\circ} \mathrm{C}$, що подовжило його тривалість на $12-14$ днів $^{2}$. При цьому слід зазначити, що продуктивність рослинницької галузі, як $\mathrm{i}$ сільського господарства в цілому, значною мірою залежить від впливу кліматичних чинників ${ }^{3}$.

Зрошення в умовах гострого дефіциту природної вологи є одним із головних чинників протидії негативним наслідкам глобального потепління та підвищення продуктивності рослинницької галузі. Оптимальна взаємодія зрошення 3 іншими складовими елементами землеробства та комплексної механізації сприяє інтенсивному використанню рослинами тепла, світла, поживних речовин, вологи, що в комплексі забезпечує ефективне використання земельних ресурсів,

\footnotetext{
1 Наукові основи охорони та раціонального використання зрошуваних земель / за наук. ред. С.А. Балюка, М.І. Ромащенка, В.А. Сташука. Київ: Аграрна наука, 2009. 624 с.

2 Сніговий В.С. Проблеми землеробства й ефективність сучасного виробництва. Таврійський науковий вісник. 2003. Вип. 27. С. 29-33.

${ }^{3}$ Бабич А.О. Світові земельні, продовольчі й кормові ресурси. Київ: Аграрна наука, 1996. 133 с.
} 
сприяє отриманню високих та сталих урожаїв різних за біологічними властивостями та генетичним потенціалом культур 4 .

Протягом XX століття зрошення набуло широкого розповсюдження у світі, натепер на планеті зрошується понад 345 млн га, що становить $21 \%$ від загальної площі ріллі, на якій виробляється понад 40\% усієї сільськогосподарської продукції, тобто продуктивність одного зрошуваного гектара більше ніж удвічі перевищує вихід рослинницької продукції 3 неполивної площі. Висока ефективність штучного зволоження зумовила вирішення продовольчої безпеки людства, оскільки стрімке зростання площ зрошуваних земель призвело до суттєвого зменшення світового індексу цін на продовольство з 2,2\% у 1971-1980 рр. до 0,8\% - у 2000-2005 pp.

Натепер унаслідок глобальних змін клімату, що проявляється у зростанні температур повітря, зменшенні його відносної вологості, зниженні кількості та порушенні рівномірності надходження атмосферних опадів, зростанні дефіциту якісної поливної води, зумовлено необхідність використання нових методологічних підходів до організації штучного зволоження як на регіональному, так і на мікролокальному рівнях ${ }^{6}$.

У багатьох країнах світу в невеликих фермерських господарствах не вистачає коштів, часу, енергії або води, оскільки існуючі технології зрошення є надзвичайно ресурсномісткими. Обробіток грунту, внесення добрив, сівба, догляд за посівами, збирання врожаю вимагають великих витрат трудових ресурсів і часу, дизельні насоси потребують палива, електричні - підключення до мереж та електроенергії, проте іноді поливна вода не потрапляє в прикореневу зону рослин, а, наприклад, випаровується в повітря (у разі поливу дощуванням), стікає за межі полів (у разі поливів поверхневим способом), переміщується в глибокі прошарки грунту й стає недоступною (поливи затопленням) ${ }^{7}$.

\section{1. Вітчизняні селекційні розробки для посушливої зони Степу України - основа формування високопродуктивних агровиробничих систем на зрошуваних землях}

Умови зрошення значно пом'якшують негативний вплив основного лімітуючого фактора в умовах Південного Степу - посухи. Але ефективне використання поливних земель можливе за умови

\footnotetext{
${ }^{4}$ Силва Ж. Г., Нвазе К. Ф., Казин Э. Достижение нулевого голода. Критическая роль инвестиций в социальную защиту и сельское хозяйство. ФАО ООН. Рим, 2016. С. 12-14.

${ }^{5}$ Gathala M. K.,, Timsina J., Islam Md. S. et cetera Conservation agriculture based tillage and crop establishment options can maintain farmers' yields and increase profits in South Asia's rice-maize systems. Evidence from Bangladesh. Field Crops Research. 2014. P. 85-98.

${ }^{6}$ Asfaw S., Maggio G. Gender integration into climate-smart agriculture. Tools for data collection and analysis for policy and research. Food and Agriculture Organization of the United Nations. Rome, 2016. 20 p.

${ }^{7}$ McCarthy N. Understanding agricultural households' adaptation to climate change and implications for mitigation: land management and investment options. Integrated Surveys on Agriculture. Washington D.C., USA: LEAD Analytics Inc. 2011. P. 42-47.
} 
розроблення моделей та створення нових генотипів сортів та гібридів, які здатні поєднувати високий урожайний потенціал та високу адаптивну здатність.

Селекційні напрями дослідження для умов південного регіону України були розпочаті професором П.І. Підгорним у 20-ті роки XX століття із зерновими культурами - кукурудзою, пшеницею, ячменем. Проте широкомасштабна наукова селекція розпочалася в Інституті з розбудовою зрошувальних систем та необхідністю створення сортів, що пристосовані до інтенсивних технологій.

Інститут зрошуваного землеробства НААН - це єдина науковадослідна установа в Україні, де створюються сорти і гібриди для зрошуваних умов, адаптовані до агроекологічних чинників степової зони вирощування, здатні ефективно використовувати поливну воду, мінеральні добрива на формування одиниці врожаю. Сьогодні в Інституті створено понад 80 високопродуктивних сортів і гібридів зернових, бобових, овочевих, кормових культур, які займають площі понад півмільйона гектарів сільськогосподарських угідь в Україні.

Селекиія і насінництво пшениці. 31964 року в інституті проводяться селекційні дослідження 3 пшениці м'якої i твердої озимої для зрошуваного землеробства степової зони України. Розроблено та вдосконалено методи селекції пшениці 3 новими інноваційними компонентами, які захищені патентами та авторськими свідоцтвами. Удосконалено модель сортів озимої пшениці для зрошуваного землеробства, теоретично обгрунтовано розвиток і практичну реалізацію програми селекції сортів універсального типу.

Натепер у Державний реєстр сортів і гібридів рослин України внесено 12 сортів пшениці м'якої озимої (Херсонська безоста, Херсонська 99, Росинка, Кохана, Овідій, Благо, Марія, Конка, Бургунка, Анатолія, Ледя, Кошова) і 3 сорти пшениці твердої озимої (Дніпряна, Кассіопея, Андромеда) селекції Інституту, крім того, в державному сортовипробуванні знаходяться сорти Соборна, Перлина Степу, Фортеця, Акварель, які в умовах зрошення на кожному гектарі забезпечують збори зерна по 8,5-12,0 т/га і не вилягають. За вирощування на неполивних ділянках урожайність цих сортів по пару 7,0-7,5 т/га, по непарових попередниках - 4,0-5,0 т/га. Створені інтенсивні сорти пшениці озимої характеризуються особливо цінними ознаками: короткостебловістю, посухостійкістю, толерантністю до хвороб, продуктивністю та якістю зерна в умовах змін клімату півдня України. Сорти селекції інституту рекомендовані для всіх еколого-географічних зон України (Степ, Лісостеп, Полісся) і займають щорічно 200-250 тис. га. Сорт пшениці Марія внесено в Реєстр сортів Туреччини, проходять реєстрацію ще два сорти. 
Селекиія $i$ насінництво кукурудзи. Селекція кукурудзи для умов зрошення пройшла в Україні історичний шлях за 50 років - від постановки задач до створення конкретних гібридів.

За результатами багаторічних досліджень розроблені методи ідентифікації селекційного матеріалу за ознаками адаптивності до вимог зрошення, методи підбору батьківських пар для схрещувань 3 метою отримання гібридів кукурудзи 3 широким адаптивним потенціалом, методи оцінки середовищ як фонів інтенсивного добору селекційного матеріалу за ознаками адаптивності. У стадії розроблення знаходяться такі важливі питання, як методи створення самозапилених ліній, адаптивних до конкретних екологічних умов, удосконалення методів добору вихідного матеріалу для умов зрошення 3 урахуванням особливостей південно-степового клімату, з'ясування оптимальних параметрів морфо-біологічних та гетерозисних моделей гібридів різних груп стиглості, адаптованих до зрошення. Практичним результатом реалізації розроблених методик $\epsilon$ створення гібридів, які здатні стабільно реалізовувати генетичний потенціал зернової продуктивності в умовах жорсткого коливання факторів зовнішнього середовища та придатні для вирощування за водозберігаючих технологій. Використання в селекції нового вихідного матеріалу дозволяє отримувати гібриди кукурудзи ФАО 190-600 з високою специфічною адаптивністю до агроекологічних та технологічних умов вирощування при зрошенні. Створено понад 50 високопродуктивних гібридів різних груп стиглості, 11 з яких занесено до Державного реєстру сортів рослин, придатних до поширення в Україні з урожайністю зерна 14-16 т/га.

Селекиія $і$ насінництво сої. Селекційна робота зі створення насіннєвих і кормових сортів сої в Інституті розпочата в 1959 році. 31967 року розпочинається новий етап селекційної роботи: створення сортів проводиться шляхом гібридизації 3 подальшим багаторазовим індивідуальним добором. Було створено 26 сортів, з яких натепер 13 у Реєстрі сортів рослин України. Сорти сої Юг 40, Юг 30, Витязь 50, Деймос, Фаетон, Аполлон, Діона, Монарх, Аратта, Софія, Даная, Святого, що створені для умов зрошення, характеризуються високою стійкістю до вилягання, до ураження пероноспорозом, бактеріальним опіком, відрізняються технологічністю і забезпечують урожайність насіння 4,5-5,2 т/га. Колекція зразків включена до Європейського каталогу генетичних ресурсів рослин EURISCO. Впровадження скоростиглих сортів відбувається в зонах Степу, Лісостепу, Полісся, середньоранніх та скоростиглих - у зоні Степу на площі 120-150 тис. га щорічно.

Селекція $i$ насінництво лючерни. Робота із селекції люцерни в Інституті розпочата з 1946 року шляхом отримання перших колекційних 
зразків люцерни з Кубанської дослідної станції ВІРа. За період 3 1946 року і дотепер у колекційних розсадниках першого і другого етапів вивчення оцінювалось більше 6 тисяч зразків.

Із середини вісімдесятих років минулого століття розвивається якісно новий етап у селекційній роботі з люцерною. Створено сорти Надєжда, Сінська інтенсивного типу, що поєднують високу насіннєву (6-9 ц/га) та кормову (700-800 ц/га) продуктивність. Зусилля селекціонерів сьогодні спрямовані на створення сортів люцерни 3 потужною кореневою системою, підвищеною азотфіксуючою здатністю. Цей напрям набуває особливої актуальності на сучасному етапі за глобальної деградації гумусу і грунтів 3 відсутністю можливостей застосування хімікотехнічних ресурсів у повному обсязі. Виконані дослідження дали можливість розробити теоретичні основи селекції люцерни, розробити методику селекції люцерни на підвищений рівень накопичення кореневої маси, що дозволило з використанням великого колекційного матеріалу люцерни зі всього світу створити в Інституті зрошуваного землеробства сорти люцерни Серафіма, Унітро, Веселка, Зоряна, Донечка, Анжеліка, Елегія з різними важливими господарсько-цінними ознаками та властивостями.

Селекція томата. Селекційна робота з культурою томата зі створення нових інтенсивних сортів була розпочата у 1981 році. Починаючи 3 2001 року, всі наукові дослідження проводяться за умови краплинного зрошення. У процесі селекційної роботи особлива увага приділяється створенню конкурентоздатних сортів 3 високим потенціалом урожайності, показниками якості продукції, придатних до механізованого збирання плодів. Промислова переробка плодів з високим вмістом сухої речовини, цукру, аскорбінової кислоти дає можливість отримати томатну продукцію високої якості. Генетичні та селекційні здобутки знайшли практичне застосування під час створення нових сортів томата, 7 я яких занесені до Реєстру сортів рослин України: Наддніпрянський 1, Кіммерієць, Сармат, Інгулецький, Тайм, Легінь, Кумач з потенційною врожайністю в разі зрошення 110-150 т/га. Усі сорти інтенсивного типу, чутливі до високого рівня агротехніки, зрошення.

Селекиія моркви. Розроблена та впроваджена технологія вирощування маточних коренеплодів моркви столової за краплинного зрошення (червневий строк сівби, розрахункова доза добрив, густота рослин 1 млн шт./га). Технологія забезпечує отримання врожайності маточних коренеплодів сорту Яскрава 60,0 т/га, що на 49,2\% більше базової. За використання маточників-штеклінгів одержано максимальний рівень рентабельності вирощування насіння моркви $120,3 \%$ та найнижчу собівартість 68,1 грн/кг. 
Насінництво картоплі. Розробка є результатом багаторічної роботи в галузі біотехнології та насінництва картоплі, зокрема, теоретичного обгрунтування та розроблення принципів створення системи насінництва картоплі для умов зрошення півдня України шляхом одержання вихідного матеріалу, отриманого поєднанням біотехнологічних методів оздоровлення та методу двоврожайної культури за подальшого його польового репродукування. Були виконані глибокі фундаментальні дослідження: вперше для умов регіону розроблено принципово нову схему відтворення еліти; багаторічні конкурсно-екологічні випробування та введення в практику сільськогосподарського виробництва високопродуктивних конкурентоспроможних сортів з високою адаптацією до грунтово-кліматичних умов півдня та вирощування двоврожайною культурою; детальна розробка основних елементів технології вирощування картоплі в культурі in vitro, використання під час відтворення насіннєвої картоплі вищих категорій унікального поєднання біотехнологічних методів оздоровлення вихідного матеріалу (термо- і хемотерапії, апікальної меристеми) і методу двоврожайної культури за польового репродукування.

\section{2. Розробка та вдосконалення інтенсивних, ресурсоощадних} та біологізованих технологій вирощування сільськогосподарських культур, що адаптовані до кліматичних змін

\section{та штучного зволоження}

Інтенсивні технології вирощування зумовлюють необхідність застосування великих обсягів ресурсів для отримання оптимальних рівнів урожайності сільськогосподарських культур. Тому важливе наукове й практичне значення має застосування інноваційних підходів до формування систем землеробства на зрошуваних землях, які базуються на принципах водо- й ресурсоощадження, нормування витрат поливної води, добрив, пестицидів і біопрепаратів, ураховують розташування кореневої системи культур, використання альтернативних джерел енергії тощо ${ }^{8}$.

В усьому світі на сільське господарство припадає близько 70\% споживання води і 30\% споживання енергії. Тому стратегічним $\epsilon$ питання зниження витрат як поливної води, так і енергії під час проведення поливів. Розуміючи, що багато сільгосптоваровиробників обмежені за ресурсним забезпеченням, учені агарної науки повинні запропонувати комплекс заходів з економії та мінімізації витрат води, енергії, праці та коштів шляхом розроблення і відпрацювання новітніх технологій, що враховують витрати цих чотирьох ресурсів, які можуть

\footnotetext{
${ }^{8}$ Снеговой В.С., Гаврилица А.О. Орошение: от древнего искусства до современной науки. Кишинев: Штипнца, 1989. 135 с.
} 
мати важливе значення та підвищити економічну ефективність ведення зрошуваного землеробства .

Краплинне зрошення у 2-3 рази зменшує витрати поливної води на одиницю посівної площі, підвищує врожайність і покращує якість рослинницької продукції. Проте найголовнішою перевагою цього способу штучного зволоження є економія ресурсів та підвищення їх окупності одиницею приросту врожаю. Краплинне зрошення завдяки його багатьом перевагам було вперше використано вже понад 100 років тому, але дотепер вимагає вдосконалення та підвищення його ресурсоощадного спрямування. Тому ресурсоощадні технології штучного зволоження необхідно адаптувати до унікальних особливостей кожного господарства та регіону ${ }^{10}$.

Перспективними для вирішення проблем зрошуваного землеробства щодо ресурсозбереження та підвищення економічної ефективності $\epsilon$ застосування мікрозрошення та насосів із живленням від сонячних батарей (рис. 1).

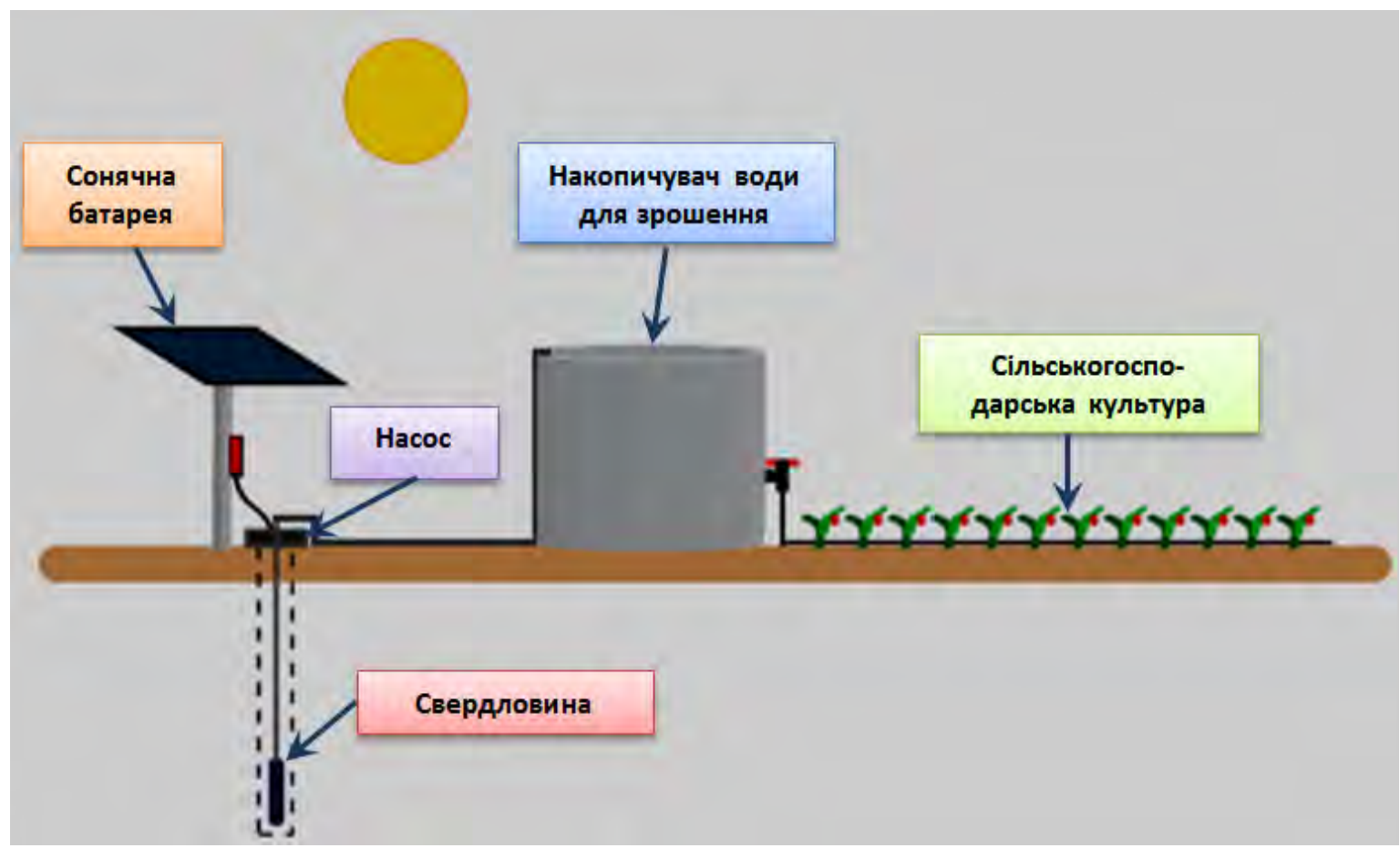

Рис. 1. Схема функціонування ресурсоощадної системи зрошення 3 використанням сонячної енергії ${ }^{11}$

\footnotetext{
${ }^{9}$ Нетіс І.Т. Зміна клімату в зоні зрошення. Зрошуване землеробство. 1994. Вип. 39. С. 7-12.

${ }^{10}$ Сніговий В.С., Жуйков Г.С., Димов О.М. Економічні важелі еколого-безпечного ведення землеробства на зрошуваних землях Південного Степу. Агроекологічний журнал. Київ, 2003. С. 32-37.

${ }^{11}$ Fischer R. A., Byerlee D., Edmeades G. O. Crop yields and global food security: Will yield increase continue to feed the world? Australian Centre for International Agricultural Research. 2014. No. 158. P. $52-$ 59.
} 
Для оптимізації зрошення, а також для зменшення витрат поливної воді та енергетичних ресурсів необхідно розробляти і впроваджувати інноваційні системи штучного зволоження з максимальним спрощенням та низькою вартістю. При цьому важливе значення має врахування локальних умов зрошення й площі поливу для виготовлення насосів. За останні роки широке розповсюдження одержали насоси 3 потужністю 40-200 Вт, які використовують для зрошення невеликих полів 3 площею від 1000 до $5000 \mathrm{~m}^{2}$. За таких умов є можливість використання для живлення таких насосів сонячних батарей та комплексування витрат на зрошення за один-два сезони вирощування сільськогосподарських культур ${ }^{12}$.

Встановлено динаміку формування найголовніших 3 точки зору впливу на інтенсивність ростових процесів та врожайність сільськогосподарських культур показників: мінімальна та максимальна температура повітря, відносна вологість повітря, швидкість вітру та інтенсивність сонячної радіації. За допомогою математичного моделювання одержано показники надходження сонячної радіації в МДж/м ${ }^{2}$ за добу шляхом пропорційного врахування параметрів загальної хмарності та температурного режиму, а також середньодобове випаровування (евапотранспірація) за методом Пенмана-Монтайта - у мм за добу.

Аналізом одержаних даних метеорологічних показників, гідротермічного коефіцієнту, сонячної радіації та евапотранспірації за умовний вегетаційний період 3 квітня по вересень доведено, що вони характеризувалися певними відмінностями в окремі роки. Найбільший діапазон коливань зафіксовано щодо надходження атмосферних опадів від 221 мм у 2006 р. до 451 мм у 2015 р. Також згідно з варіаційним аналізом показники кількості атмосферних опадів характеризувалися найбільшою мінливістю, а коефіцієнт варіації становив 27,5\%. Гідротермічний коефіцієнт Селянінова, який відображає природну зволоженість території, також мав високе варіювання $-28,3 \% 3$ коливаннями від 0,61 (2012 р.) до 1,34 (2008 р.).

Цікаві результати відобразив лінійний кореляційно-регресійний аналіз досліджуваних показників (рис. 2). Сформовані лінії тренду свідчать про високий рівень наростання за досліджуваний період кількості опадів (позначка 1), сум температур повітря понад $10^{\circ} \mathrm{C}(2)$ та евапотранспірації (7). Відносна вологість повітря (4) та швидкість вітру (5) характеризувалися практично повною стабільністю протягом 2005-2016 років, а надходження сонячної енергії на $1 \mathrm{~m}^{2}$ (6) проявило тенденцію до зниження.

\footnotetext{
${ }^{12}$ Resource-smart technology. Bridging the design gap between the developed and developing worlds. URL: https://www.ideglobal.org/story/resource-smart-technology\# (дата звернення 12.01.2019).
} 


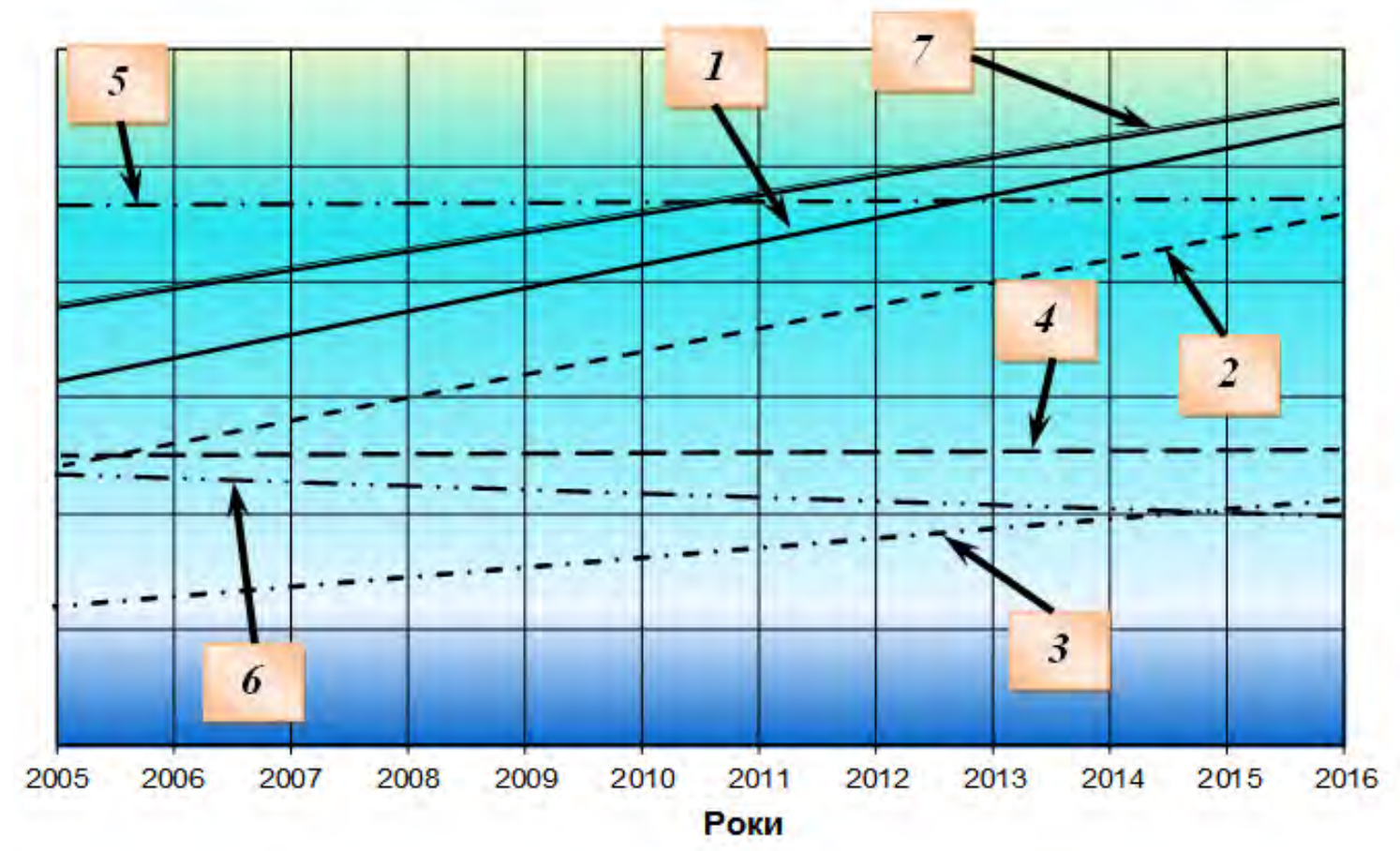

Рис. 2. Графічне відображення результатів кореляційно-регресійного аналізу метеорологічних показників, сонячної радіації та евапотранспірації за період 3 квітня по вересень місяці у роки проведення досліджень:

1 - кількість опадів, мм ( $\left.\mathrm{y}=10,077 \mathrm{x}-19947 ; \mathrm{R}^{2}=0,7821\right) ; 2$ - сума температур повітря понад $10^{\circ},{ }^{\circ} \mathrm{C}(\mathrm{y}=20,119 \mathrm{x}-36968 ; \mathrm{R} 2=0,7549) ; 3$ - гідротермічний коефіцієнт ( $\left.\mathrm{y}=0,0235 \mathrm{x}-46,269 ; \mathrm{R}^{2}=0,9104\right) ; 4$ - відносна вологість повітря, \% $\left(\mathrm{y}=0,0308 \mathrm{x}-1,0718 ; \mathrm{R}^{2}=0,6816\right) ; 5$ - швидкість вітру, м/c $(\mathrm{y}=0,00,21 \mathrm{x}-1,8345$; $\left.\mathrm{R}^{2}=0,7212\right) ; 6$ - надходження сонячної енергії, МДж/м 2 за добу $(\mathrm{y}=-0,0255 \mathrm{x}+$ $\left.+69,975 ; \mathrm{R}^{2}=0,7151\right) ; 7$ - евапотранспірація, мм/доба $(\mathrm{y}=0,0668 \mathrm{x}-129,99$; $\left.\mathrm{R}^{2}=0,9421\right)$

Слід зауважити, що, незважаючи на зростаючу кількість опадів за лінією тренду, рівномірність їх надходження протягом вегетаційного періоду сільськогосподарських культур, причому в останні 5-7 років, істотно зросла непродуктивна кількість опадів.

У природно-кліматичному відношенні Південний Степ України характеризується високим забезпеченням тепловими ресурсами, на фоні якого протягом останніх років відбуваються кліматичні зміни, що здебільшого прирівнюються до явищ глобального потепління. Так, за останні десятиліття середньорічна температура повітря зросла на $1,9^{\circ} \mathrm{C}$, а в літні місяці - на $3,6-3,9^{\circ} \mathrm{C}$, досягаючи в липні максимального середньодобового показника $24,6^{\circ} \mathrm{C}$.

Вирощування сільськогосподарських культур пов'язано 3 дією та взаємодією багатьох факторів, про що свідчить вплив природних та антропогенних умов. На рівні кожного господарства 3 метою підвищення екологічності агротехнічних і меліоративних заходів та 
способів ведення сільського господарства необхідно оцінювати їхній вплив на грунти та агроекосистеми. Розрахунками доведено, що для забезпечення максимальної продуктивності зрошення у великотоварних господарствах, які мають тваринництво, найбільшу питому вагу в сівозмінах по 40-45\% необхідно надати зерновим та кормовим культурам. У господарствах, які спеціалізуються на виробництві зерна і технічних культур, під час формування сівозмін слід надати абсолютну перевагу на рівні 50-60\% зерновим культурам, у тому числі пшениці озимій $-20-25 \%$; кукурудзі - 20-25\%, а також технічним культурам, головно сої - 20-25\%. У господарствах овочевого напряму питома вага овочевих культур та картоплі повинна бути збільшеною до 50-60\% за рахунок обмеження площ під зерновими і кормовими культурами. За використання краплинного зрошення питому вагу овочів та картоплі слід підвищити до 80\%.

На півдні України найбільш дієвим заходом покращення водного режиму грунту $є$ штучне зволоження, яке дає змогу істотно підвищити продуктивність сільського господарства. Багаторічними польовими дослідами Інституту зрошуваного землеробства Національної академії аграрних наук України та інших наукових установ доведено, що за рахунок штучного зволоження $\epsilon$ можливість створювати сприятливі умови для реалізації потенційних можливостей сортів і гібридів, а також забезпечити істотне зростання обсягів виробництва валової продукції рослинництва з одиниці посівної площі.

Підвищення ефективності наукових досліджень та конкурентоспроможності наукових розробок у галузі зрошуваного землеробства в південному регіоні України є вагомим важелем стабілізації виробництва аграрної продукції в умовах посушливого клімату та одним із пріоритетних напрямів державної політики. Інститутом зрошуваного землеробства НААН було розроблено та постійно вдосконалюються системи зрошуваного землеробства в областях степової зони, які дозволяють отримувати в 3-5 разів вищу врожайність сільськогосподарських культур, порівняно з неполивними умовами, а режими зрошення, зорієнтовані на біологічні та генетичні особливості сучасних сортів і гібридів, дозволяють економити 15-40\% поливної води фактично без втрат урожаю.

Теоретичні розробки щодо оптимізації грунтових процесів на зрошуваних землях обгрунтовують наукові основи раціонального та екологічно-безпечного застосування добрив і меліорантів. Широкого розповсюдження набула нова ресурсозберігаюча система удобрення сільськогосподарських культур, яка щорічно впроваджувалася в районах Херсонської, Миколаївської, Дніпропетровської областей на площі 50 тис. га і забезпечила зниження витрат мінеральних добрив на 24-72\% порівняно із прийнятими нормами. Розробки Інституту ввійшли 
складовою частиною до «Перспективного плану збереження i підвищення родючості грунтів Херсонської області».

Впровадження «Методики визначення окупності поливної води та відшкодування витрат на їі подачу», розробленої Інститутом зрошуваного землеробства НААН, дозволить підвищити ефективність функціонування водогосподарського комплексу і зрошуваного землеробства південного регіону в цілому, більш раціонально розподіляти кошти.

Розробки Інституту становлять науково-технічну базу ведення землеробства на зрошуваних землях у південному регіоні. У сівозмінах 3 короткою ротацією широкого поширення в регіоні набула розроблена система грунтозахисного енергозберігаючого обробітку грунту, яка забезпечує економію паливно-мастильних матеріалів (на 20\%), зі зниженням енергоємності процесу (на 40\%). Удосконалені в Інституті технології вирощування сільськогосподарських культур упроваджуються на зрошуваних землях у Херсонській, Миколаївській, Одеській та Дніпропетровській областях на площі (тис. га): пшениця озима - 150, соя - 35, овочеві культури - 25. Водозберігаючі режими зрошення сільськогосподарських культур, що забезпечують економію поливної води, енергоресурсів та отримання 4,5-5,5 млн грн чистого прибутку, використовуються в господарствах Херсонської, Миколаївської, Дніпропетровської, Запорізької областей на площі 300 тис. га.

У польових дослідах Інституту зрошуваного землеробства встановлено, що завдяки кращим показникам щільності складення, пористості та водопроникності запаси вологи на час відновлення весняної вегетації озимих і появи сходів ярих культур за різноглибинних систем полицевого і безполицевого обробітку були на 3,5-7\% вищими, ніж за мілкого одноглибинного. Витрати води на формування однієї тони продукції у всіх сівозмінах найбільш низькими були за різноглибинної оранки і коливалися від $723 \mathrm{~m}^{3} / \mathrm{T}$ у сівозміні $375 \%$ насиченням зерновими до $973 \mathrm{~m}^{3} /$ т за зменшення питомої ваги зернових культур до $50 \%$ та до $1100 \mathrm{~m}^{3} / \mathrm{T}$ - до 25\%. Подібна закономірність відзначається і за систем різноглибинного та одноглибинного мілкого безполицевого, зі зменшенням відповідно на 5-10\% та 50-60\%.

Більш сприятливі умови для накопичення поживних речовин у шарі грунту 0-40 см створювалися на початку весняної вегетації сільськогосподарських культур у сівозміні 3 75\% насиченням зерновими культурами і на фоні різноглибинного основного обробітку з обертанням скиби.

Заміна оранки на безполицевий глибокий основний обробіток призводила до зниження вмісту нітратів, рухомого фосфору та обмінного калію відповідно на 10, 17 та 8\%, а в разі застосування мілкого безполицевого розпушування ці показники були нижчими 
відповідно на 27, 23 та 13\%. Подібна закономірність відмічалася і в сівозмінах № 1 з 25 та № 2 з 50\% насиченням зерновими культурами, водночас показники вмісту поживних речовин були істотно нижчими.

Найвищу врожайність культур і продуктивність сівозмін забезпечила сівозміна № 3 з 3 75\% насиченням зерновими і $25 \%$ технічними культурами за різноглибинного обробітку 3 обертанням скиби, де іiі показники становили 10,3 т/га, 3 прибутком 37,9 тис. грн і рівнем рентабельності $187 \%$ (рис. 3 ).

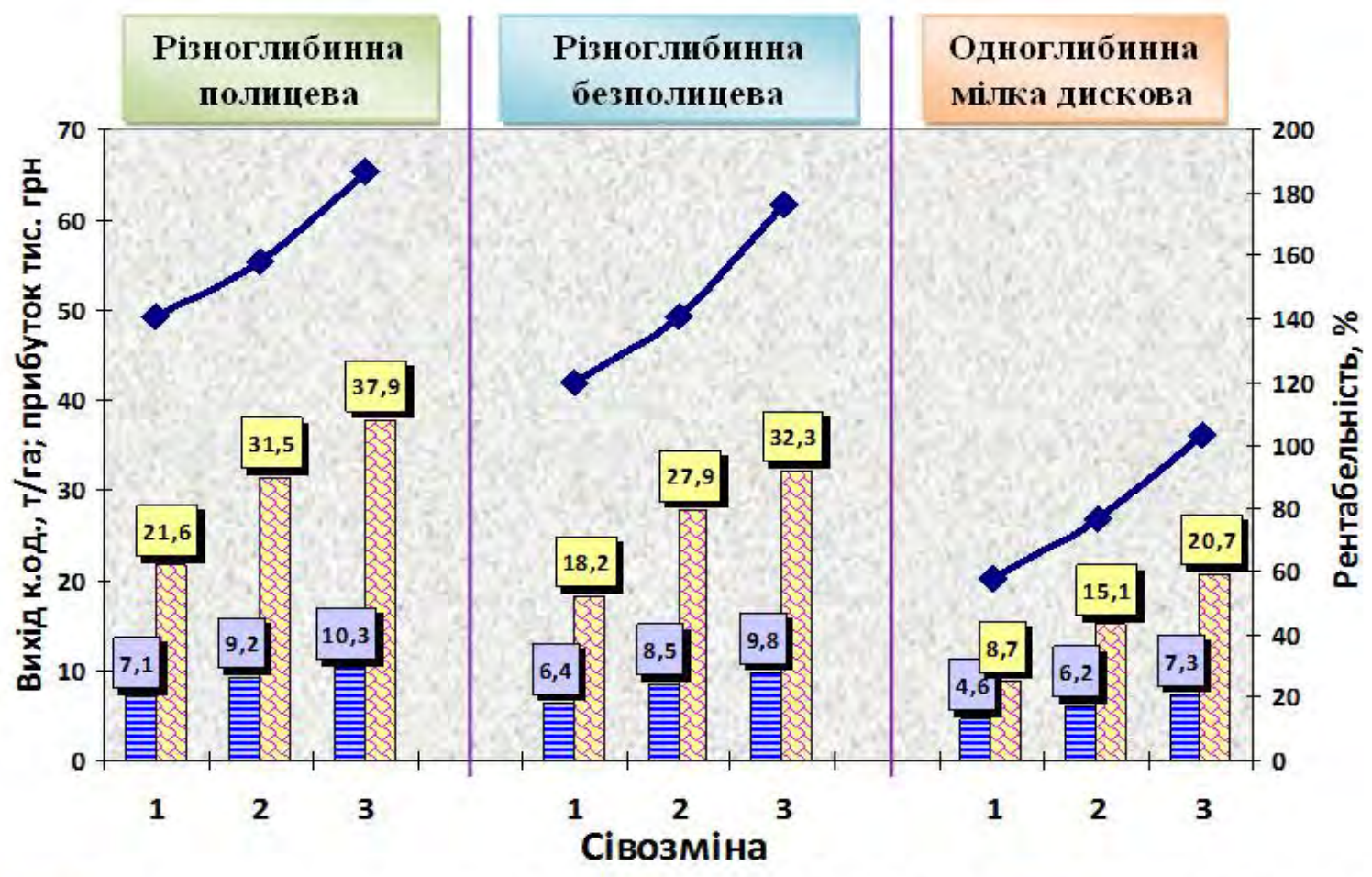

— Вихід кормових одиниць, т/га इसख Прибуток, тис. грн $\rightarrow$ Рентабельність, \%

\section{Рис. 3. Показники продуктивності та економічної ефективності функціонування сівозмін за різних систем обробітку грунту}

Водночас за одноглибинної мілкої рівень рентабельності знизився до $103 \%$. У першій і другій сівозмінах прибуток та рівень рентабельності були істотно нижчими, водночас закономірність відносно способів і глибини основного обробітку збереглася.

У польових дослідах за напрямом оптимізації технології вирощування нових гібридів кукурудзи різних груп ФАО за різних способів поливу та якості поливної води визначено рівень мінералізації, іонно-сольовий склад зрошувальної води та зроблено ії іригаційну оцінку згідно 3 ДСТУ-2730-2015. Отримано базову інформацію щодо економічної ефективності комплексної дії нових гібридів кукурудзи, різних способів поливу в умовах Інгулецької та Каховської зрошувальних систем. 
3'ясовано, що в разі поливу водою II класу з Інгулецької зрошувальної системи урожайність гібридів кукурудзи знижувалась на 5-10\% порівняно 3 результатами досліджень, отриманих на Каховському зрошуваному масиві (табл. 1).

Таблиця 1

Урожайність зерна гібридів кукурудзи за різних способів поливу та режиму зрошення, т/га (середнс за 2016-2018 рр.)

\begin{tabular}{|c|c|c|c|c|c|c|}
\hline № & Гібрид & ФАО & $\begin{array}{c}\text { Полив } \\
\text { дощуванням } \\
\text { ДДА 100МА, } \\
\text { Інгулецький } \\
\text { зрошувальний } \\
\text { масив, перед- } \\
\text { поливна } \\
\text { вологість 80\% } \\
\text { НВ }\end{array}$ & $\begin{array}{c}\text { Полив } \\
\text { краплинним } \\
\text { зрошенням, } \\
\text { Інгулецький } \\
\text { зрошувальний } \\
\text { масив, перед- } \\
\text { поливна } \\
\text { вологість 85\% } \\
\text { НВ }\end{array}$ & $\begin{array}{c}\text { Полив } \\
\text { краплинним } \\
\text { зрошенням, } \\
\text { Каховський } \\
\text { зрошувальний } \\
\text { масив, перед- } \\
\text { поливна } \\
\text { вологість 85\% } \\
\text { НВ }\end{array}$ & $\begin{array}{c}\text { Полив } \\
\text { дощуванням } \\
\text { Зематік, } \\
\text { Каховський } \\
\text { зрошувальний } \\
\text { масив, перед- } \\
\text { поливна } \\
\text { вологість } 80 \% \\
\text { НВ }\end{array}$ \\
\hline 1 & ДН Пивиха & 190 & 9,75 & 10,10 & 10,76 & 10,57 \\
\hline 2 & Оберіг & 190 & 10,61 & 11,00 & 12,10 & 11,54 \\
\hline 3 & Хотин & 250 & 12,61 & 12,29 & 13,41 & 13,97 \\
\hline 4 & Галатея & 250 & 12,21 & 11,91 & 13,46 & 12,71 \\
\hline 5 & Корунд & 280 & 12,38 & 12,64 & 12,54 & 12,42 \\
\hline 6 & Росток & 300 & 12,93 & 14,81 & 15,65 & 12,85 \\
\hline 7 & Збруч & 350 & 12,77 & 14,87 & 15,20 & 12,81 \\
\hline 8 & Вiзир & 350 & 10,61 & 11,43 & 11,72 & 11,48 \\
\hline 9 & Каховський & 350 & 11,23 & 13,72 & 13,28 & 11,37 \\
\hline 10 & Азов & 380 & 14,09 & 14,25 & 15,34 & 14,57 \\
\hline 11 & Рава & 420 & 14,65 & 15,81 & 16,27 & 14,38 \\
\hline 12 & Арабат & 430 & 14,30 & 18,71 & 18,95 & 14,83 \\
\hline \multicolumn{2}{|c|}{$\mathrm{HIP}_{05}$} & & 0,37 & 0,56 & 0,42 & 0,44 \\
\hline
\end{tabular}

За дощування найвищу врожайність зерна на рівні 14,1-18,8 т/га формували гібриди з ФАО 380-430 Азов і Арабат, а за краплинного зрошення абсолютну перевагу мав гібрид Арабат, урожайність зерна якого підвищилася до 18,7-19,0 т/га.

Одним із головних чинників інтенсифікації виробництва продукції в зрошуваному землеробстві $\epsilon$ селекційні розробки. В Інституті зрошуваного землеробства створюються новітні сорти і гібриди 3 генетично зумовленою адаптивністю до умов зрошення. Створено понад 70 сортів і гібридів пшениці озимої, сої, кукурудзи, люцерни, томатів та інших культур.

Сорти пшениці озимої мають потенціал урожайності 8-11 т/га зерна та високу адаптивну здатність. Нові сорти люцерни поєднують у собі високі потенціали кормової, насіннєвої та азотфіксуючої продуктивності 3 широкими адаптаційними властивостями до біотичних та абіотичних умов довкілля, здатні накопичувати у грунті до 2,7 ц/га біологічного 
азоту. Створено високопродуктивні сорти сої різних груп стиглості, 3 рівнем урожайності 3,7-5,6 т/га насіння, високим вмістом білка 39-42\% та жиру 20-23\%. Нові сорти і гібриди, окрім цього, мають перевагу по стійкості до хвороб і вилягання.

Ефективність агротехнологій на зрошуваних землях підтверджена їх масштабним впровадженням. В умовах півдня України розроблена система обробітку грунту застосовується на площі 200-215 тис. га. Ресурсозберігаюча система удобрення сільськогосподарських культур 3 використанням оптимальних параметрів умісту елементів живлення у грунті впроваджена на площі 57,5 тис. га. При цьому економія ресурсів у середньому становила 150 грн/га. У Херсонській області впроваджується технологія вирощування томатів із застосуванням у технологічному процесі сортів власної селекції. Вона забезпечила максимальну врожайність 115 т/га плодів, із вмістом сухих речовин у плодах до 7\%. Обсяг впровадження - 1600-2500 га 3 перспективою розширення до 10 тис. га.

Зрошувальні системи України будувались 3 метою вирішення проблем, пов'язаних із забезпеченням продовольчої безпеки найбільш посушливої частини Степової зони. Інститут зрошуваного землеробства НААН здійснює наукове забезпечення інтенсивної системи землеробства на зрошуваних землях, стратегічним завданням якої $\mathrm{\epsilon}$ створення зони гарантованого виробництва продовольчого і фуражного зерна, розвитку молочного та м'ясного скотарства, овочівництва та виробництва кормів з адаптацією до конкретних земельних, грунтовокліматичних i організаційно-господарських умов землекористувачів. Відповідно до них відпрацьовано структуру посівних площ, сівозміни, системи удобрення, обробітку грунту та захисту рослин, які забезпечують високу продуктивність культур і фінансову віддачу для товаровиробників, що ведуть господарську діяльність у зоні функціонування зрошувальних систем.

Для великотоварних багатогалузевих сільськогосподарських підприємств 3 розвиненою тваринницькою галуззю - молочним і м'ясним скотарством - Інститутом розроблено структуру посівних площ на зрошенні, де кормові культури люцерна, кукурудза на силос і зелений корм, багатокомпонентні злаково-бобові сумішки займають до $45 \%$ посівних площ, зернові - кукурудза на зерно, пшениця озима та ячмінь також 45 , а технічні - до $10 \%$. Запровадження плодозмінних сівозмін різної ротації з відповідними технологіями вирощування забезпечує високу кормову та зернову продуктивність і створює умови для збереження i відтворення родючості та сприятливого меліоративного стану грунтів.

Для великотоварних господарств 3 виробництва продукції для промислової переробки визначено структуру посівних і сівозміни, де 
зернові культури займають 50\% посівних площ, а друга половина ріллі відводиться під вирощування технічних культур. Пріоритетне місце у структурі посівних площ відводиться кукурудзі на зерно, сої, пшениці та ріпаку озимим - для промислової переробки. 3 метою реалізації потенційних можливостей продуктивності сортів і гібридів сільськогосподарських культур розроблено органо-мінеральну систему удобрення 3 використанням на добриво розрахункових доз мінеральних добрив і всієї листостеблової маси культур сівозмін, що забезпечує позитивний розрахунковий баланс гумусу та сприятливий фітосанітарний i меліоративний стан.

Для великотоварних господарств, що спеціалізуються на виробництві овочевих культур і картоплі, для забезпечення промислових центрів держави та зон відпочинку Інститутом розроблено структуру посівних площ, відповідно до якої під ці культури відводиться 50\% зрошуваних площ, з яких на 25\% вирощуються зернові колосові, а на 25\% площ, що залишаються, доцільно розмістити кормові культури. Насамперед це багаторічні бобові трави на сіно і зелений корм та злаково-бобові травосумішки, як на корм, так і на сидерати, що гарантує отримання продукції високої якості, в тому числі для дитячого і дієтичного харчування.

Розроблено інноваційну технологію насінництва картоплі для умов зрошення півдня України шляхом одержання вихідного матеріалу, отриманого поєднанням біотехнологічних методів оздоровлення та методу двоврожайної культури. При цьому насіннєвий матеріал вирощується в культурі in vitro, проводиться відтворення насіннєвої картоплі вищих категорій унікального поєднання біотехнологічних методів оздоровлення вихідного матеріалу (термо- і хемотерапії, апікальної меристеми) та методу двоврожайної культури за польового репродукування.

Високопродуктивною галуззю рослинництва на крайньому півдні України є рисівництво. Повне задіяння рисових систем дасть можливість довести площі посіву рису до 30-35 тис. га, і за врожайності 6,5-7,0 т/га на 90-95\% забезпечити потреби держави в зерні цієї цінної дієтичної культури. Окрім того, рис є не тільки меліорантом, а і страховою стратегічною культурою для забезпечення продовольчої безпеки України в умовах глобальних і регіональних змін клімату.

Інститут зрошуваного землеробства НАAН - це єдина науковадослідна установа в Україні, де створюються сорти і гібриди в зрошуваних умовах, адаптовані до агроекологічних умов степової зони вирощування, здатні ефективно використовувати поливну воду, мінеральні добрива на формування одиниці врожаю. Крім того, проводиться масштабна селекційна робота зі створення сортів і гібридів для неполивних умов Південного Степу України, які здатні формувати 
високі та якісні врожаї за умови дефіциту опадів, високих температур та низької вологості повітря. Сьогодні створено понад 80 високопродуктивних сортів і гібридів зернових, бобових, овочевих, кормових культур, які займають площі понад півмільйона гектарів сільськогосподарських угідь в Україні. За результатами багаторічних досліджень розроблені методи ідентифікації селекційного матеріалу за ознаками адаптивності та методи підбору для схрещувань 3 метою отримання сортів і гібридів з широким адаптивним потенціалом.

Широке виробниче впровадження розробок Інституту зрошуваного землеробства НААН підтверджує їхню високу економічну ефективність 3 отриманням 3 одного гектару сівозмінної площі в середньому $9,1-12,8$ т/га кормових одиниць, 8,5-10,0 тис. грн умовно чистого прибутку за рівня рентабельності $128-144 \%$. За рахунок нормування витрат ресурсів досягається економія поливної води, мінеральних добрив, паливно-мастильних матеріалів на 15-30\%.

\section{ВИСНОВКИ}

Таким чином, за умови змін клімату в зрошуваному землеробстві України необхідно використовувати інтенсивні технології вирощування сільськогосподарських культур, які базуються на використанні інноваційних засад 3 оптимізацією різних способів поливу та режимів зрошення, системи удобрення, обробітку грунту та захисту рослин. Запропоновано структуру посівних площ і сівозмін на зрошуваних землях України для раціонального використання зрошуваних земель та запобігання негативного впливу зовнішніх чинників природного та антропогенного характеру. Розроблено методологічні та методичні підходи інтегральної оцінки зрошуваних земель для їх раціонального використання, запобігання розвитку деградаційних процесів, охорону та відтворення родючості. Удосконалено ресурсоощадні технології вирощування різних за біологічними властивостями культур 3 дотриманням проектних нормативних витрат, які встановлені вченими Інституту зрошуваного землеробства та інших наукових установ НАAН, запропоновано наукові підходи 3 державно-приватного партнерства в систему та управління водними ресурсами, визначено інструменти державної підтримки та регулювання підприємницької діяльності в галузі зрошуваного землеробства.

Найважливішими на найближчу перспективу будуть питання зменшення всіх видів ресурсних втрат на зрошення та інші елементи агротехнологій в умовах глобальних змін клімату. Для цього необхідно відпрацювати нові наукові підходи щодо застосування інноваційних технологій краплинного зрощення на засадах мінімізації витрат води, енергії, праці та коштів, нормування поливної води, добрив, пестицидів і 
біопрепаратів, урахування розташування кореневої системи культур для визначення оптимальних поливних норм, використання сонячної енергії для альтернативних джерел енергії тощо.

Селекційні розробки Інституту зрошуваного землеробства НАAН мають важливе практичне значення, оскільки спрямовані на забезпечення агровиробників Херсонської, Миколаївської, Одеської та інших областей України високоякісним насіннєвим матеріалом. Вітчизняні сорти i гібриди за потенціалом продуктивності не поступаються закордонним сортозразкам, а за адаптивністю та стійкістю до несприятливих погодних чинників істотно переважають їх. Крім того, сорти і гібриди нашого Інституту створені у зрошуваних умовах i тому характеризуються найкращою реакцією на зрошення, мають високі показники окупності поливної води та добрив на одиницю врожаю, а значить, і максимальну економічну ефективність.

\section{АНОТАЦІЯ}

Підвищення посушливості клімату викликало необхідність зміни підходів до формування систем ведення землеробства, особливо в умовах Південного Степу України. Таким чином, за умови змін клімату в зрошуваному землеробстві України необхідно використовувати інтенсивні технології вирощування сільськогосподарських культур, які базуються на використанні інноваційних засад з оптимізацією різних способів поливу та режимів зрошення, системи удобрення, обробітку грунту та захисту рослин. Запропоновано структуру посівних площ і сівозмін на зрошуваних землях України для раціонального використання зрошуваних земель та запобігання негативного впливу зовнішніх чинників природного та антропогенного характеру. Розроблено методологічні та методичні підходи інтегральної оцінки зрошуваних земель для їх раціонального використання, запобігання розвитку деградаційних процесів, охорону та відтворення родючості. Удосконалено ресурсоощадні технології вирощування різних за біологічними властивостями культур із дотриманням проектних нормативних витрат, які встановлені вченими Інституту зрошуваного землеробства та інших наукових установ НАAН, запропоновано наукові підходи 3 державно-приватного партнерства в систему та управління водними ресурсами, визначено інструменти державної підтримки та регулювання підприємницької діяльності в галузі зрошуваного землеробства.

\section{ЛIТЕРАТУРА}

1. Наукові основи охорони та раціонального використання зрошуваних земель / за наук. ред. С.А. Балюка, M.I. Ромащенка, В.А. Сташука. Київ : Аграрна наук, 2009. 624 с. 
2. Сніговий В.С. Проблеми землеробства й ефективність сучасного виробництва. Таврійський науковий вісник. 2003. Вип. 27. С. 29-33.

3. Бабич А.О. Світові земельні, продовольчі і кормові ресурси. Київ : Аграрна наука, 1996. 133 с.

4. Силва Ж.Г., Нвазе К.Ф., Казин Э. Достижение нулевого голода. Критическая роль инвестиций в социальную защиту и сельское хозяйство. ФАО ООН. Рим, 2016. С. 12-14.

5. Conservation agriculture based tillage and crop establishment options can maintain farmers' yields and increase profits in South Asia's rice-maize systems / M.K. Gathala at al. Evidence from Bangladesh. Field Crops Research. 2014. P. 85-98.

6. Asfaw S., Maggio G. Gender integration into climate-smart agriculture. Tools for data collection and analysis for policy and research. Food and Agriculture Organization of the United Nations. Rome, 2016. 20 p.

7. McCarthy N. Understanding agricultural households' adaptation to climate change and implications for mitigation: land management and investment options. Integrated Surveys on Agriculture. Washington D.C., USA : LEAD Analytics Inc., 2011. P. 42-47.

8. Снеговой В.С., Гаврилица А.О. Орошение: от древнего искусства до современной науки. Кишинев : Штипнца, 1989. 135 с.

9. Нетіс І.Т. Зміна клімату в зоні зрошення. Зрошуване землеробство. 1994. Вип. 39. С. 7-12.

10. Сніговий В.С., Жуйков Г.С., Димов О.М. Економічні важелі еколого-безпечного ведення землеробства на зрошуваних землях Південного Степу. Агроекологічний журнал. Київ, 2003. С. 32-37.

11. Fischer R.A., Byerlee D., Edmeades G.O. Crop yields and global food security: Will yield increase continue to feed the world? Australian Centre for International Agricultural Research. 2014. №. 158. P. 52-59.

12. Resource-smart technology. Bridging the design gap between the developed and developing worlds. URL: https://www.ideglobal.org/story/ resource-smart-technology\# (дата звернення: 12.01.2019).

\section{Information about author:}

Vozhehova R. A.,

Doctor of Agricultural Science, Professor, Corresponding Member the National Academy of Agrarian Sciences of Ukraine, Director Institute Irrigated Agriculture of the National Academy Agrarian Sciences of Ukraine Naddnipryanske sett., Kherson, 73483, Ukraine 